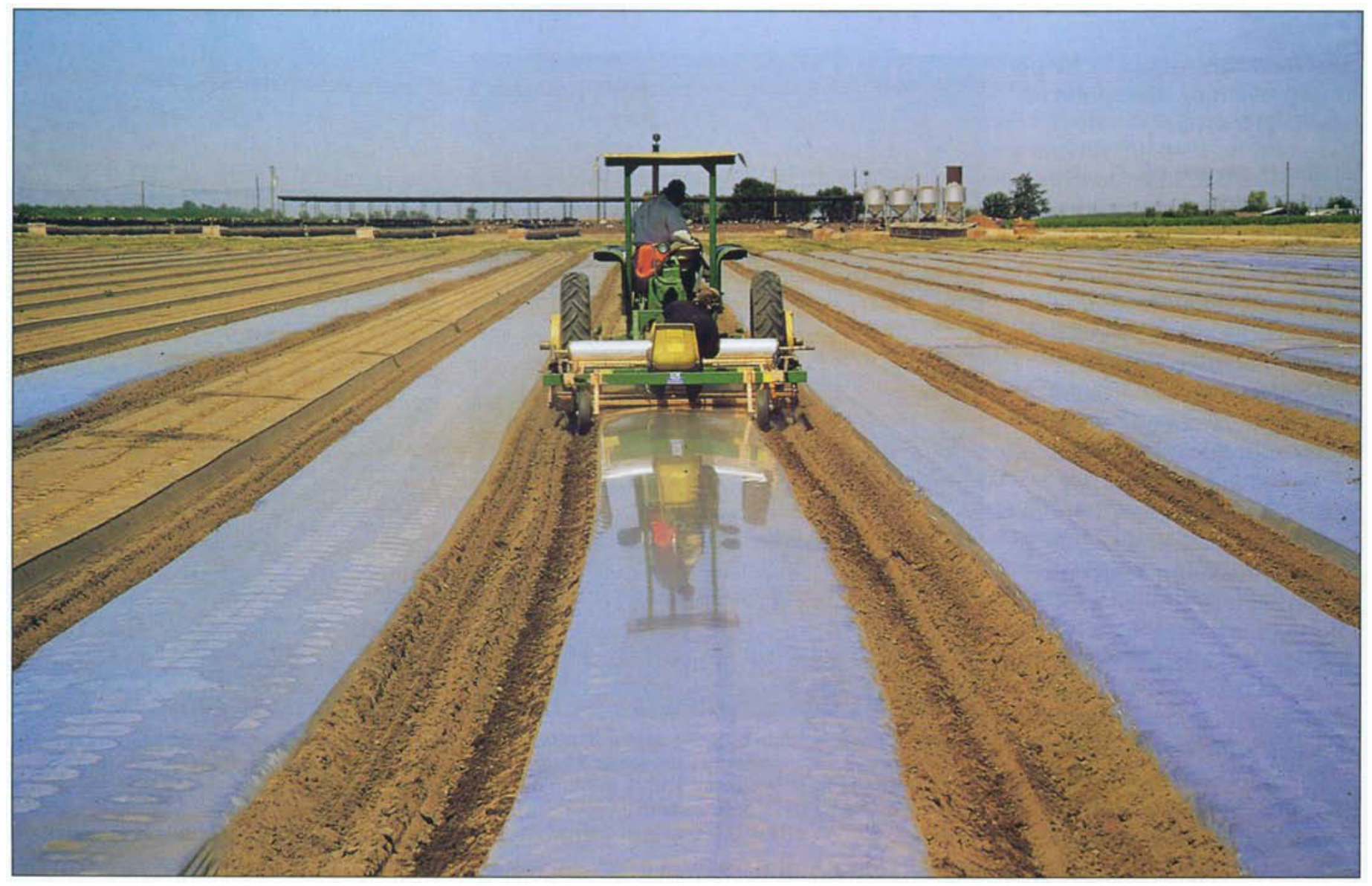

Transparent polyethylene film is applied to solarize a fleld on an organic vegetable farm in the San Joaquin Valley.

\section{Solarization and biofumigation help disinfest soil}

\author{
James J. Stapleton a Clyde L. Elmore a James E. DeVay
}

\begin{abstract}
Preplant soil fumigation with methyl bromide is scheduled to be phased out by 2005. Chemical and nonchemical alternatives are being researched and identified. Soil solarization and/or biofumigation can help fill the gap in certain cases. These alternative methods of soil disinfestation are also of value to organic growers, home gardeners and others who will not or cannot use the soil fumigation chemicals employed by many conventional commercial growers.
\end{abstract}

Goilborne pests and pathogens, in$\checkmark$ cluding weed propagules, nematodes, insects, fungi, bacteria and certain other agents, can be limiting factors in the production of crops. One of the principal strategies used by growers of high-value horticultural crops to combat these organisms is preplant soil disinfestation, using pesticides or other physical or biological methods. Soil fumigants are the most effective soil disinfestation chemicals, and methyl bromide (MB) is the most important soil fumigant chemical used by growers in California and around the world. It is a broad-spectrum pesticide with excellent activity against most potential soil pests.

Apart from controlling major soilborne pathogens and pests, soil fumigation with $\mathrm{MB}$ and other fumigants frequently provides increased crop growth and yield responses, even when pest control does not appear to be a factor. Although the mechanisms of these increases have not been fully explained, control of minor pathogens and liberation of soluble mineral nutrients in soil are involved (Chen et al. 1991).

This stimulation of crop growth resulting from soil fumigation is important to producers of many high-value agricultural commodities to assure maximum returns on their investments. Consumption of MB for preplant fumigation in California is estimated at 16 million pounds annually - nearly $50 \%$ of the total amount used 
in the United States. The fumigant is used primarily for production of strawberries, fruit and nut crop orchards and vineyards, vegetable crops and nurseries.

However, MB was identified as a risk to the stratospheric ozone layer in 1992 and targeted for worldwide phaseout in 1997 by means of the Montreal Protocol, an international treaty. Under the current terms of the agreement and of the federal Clean Air Act, preplant consumption of MB in the United States is scheduled to be gradually phased out by 2005 (USDA 2000).

The impending loss of MB as a soil fumigant has stimulated intensive efforts to develop and implement suitable replacement strategies. One of the difficulties in replacing MB is that the compound is very useful in a wide range of operations that are important in California agriculture. MB is not the first major soil fumigant pesticide removed from use in California over the past 25 years due to regulatory actions by various governmental agencies; DBCP (1,2-dibromochloropropane) and EDB (ethylene dibromide) have both lost their registration, and 1,3dichloropropene (Telone II) was suspended for several years.

UC scientists have been continuously working to develop usable alternatives for soil disinfestation. Many of the replacement treatments for methyl bromide will be other chemical products that remain available, including 1,3-dichloropropene, metam sodium and chloropicrin, applied alone or in combination. In addition, registration is being sought for chemical fumigants not currently allowed for use in agriculture, such as methyl iodide and propagyl bromide (Stapleton, in press). Apart from synthetic chemical alternatives, numerous nonchemical strategies have also been researched, field validated and in some cases implemented commercially. For certain situations, soil solarization and biofumigation are among the most useful of the nonchemical disinfestation methods.

\section{Disinfesting with solar heat}

The use of clear polyethylene film to cover moistened soil and trap lethal amounts of heat from solar radiation was first reported by Katan and colleagues in Israel in the mid-1970s (Katan 1987). DeVay and associates at UC Davis began an intensive research program on the promising technique shortly thereafter, and the term "soil solarization" was soon coined to describe the process by cooperators in the San Joaquin Valley. Researchers found that solarization could be a useful soil disinfestation method, especially in areas with hot and arid conditions during the summer months, such as the Central Valley and southern deserts. In certain cases, the treatment has also been effective, primarily for weed management, in cooler coastal areas (Elmore et al. 1993). The pesticidal activity of solarization was found to stem from a combination of physical, chemical and biological effects, as described in several comprehensive reviews (Katan 1987; Chen et al. 1991; DeVay et al. 1991; Stapleton 1998, 2000).

Although solarization can provide excellent soil disinfestation under suitable conditions, it has significant limitations and should not be considered a cure-all or universal replacement for MB. For example, solarization is most effective close to the surface of the soil under climatic and weather conditions of high air temperature and long days for soil heating. It will not control all pest organisms, may require that land be taken out of production for 3-to-6week treatments during the summer months, and requires disposal of used plastic film. Therefore its practical value to the user must be assessed by several factors, including extent and predictability of pesticidal efficacy, effect on crop growth and yield, economic cost/benefit and personal pestmanagement philosophy (Stapleton 1997).

\section{A Patterson turf grower checks soll tem- perature during solarization.}

\section{Adaptability of solarization}

Solarization has considerable versatility, being adaptable to various agricultural production applications.

Protected culture. Worldwide, probably the major commercial use of solarization is in conjunction with greenhouse/glasshouse/plastic-house culture, especially in regions where the protected crops are grown only in the winter. The empty structures can be closed in the heat of the summer and plastic film laid on the soil for solarization. This method of double insulation provides a still-air chamber above the solarized soil for added heating and greater efficacy. Greenhouse solarization is used primarily in Japan, the Near East and other Mediterranean countries (Stapleton 1997).

Nursery production. Solarization without combination with a chemical pesticide is not suitable for open afield nursery production, due to zero toler- 


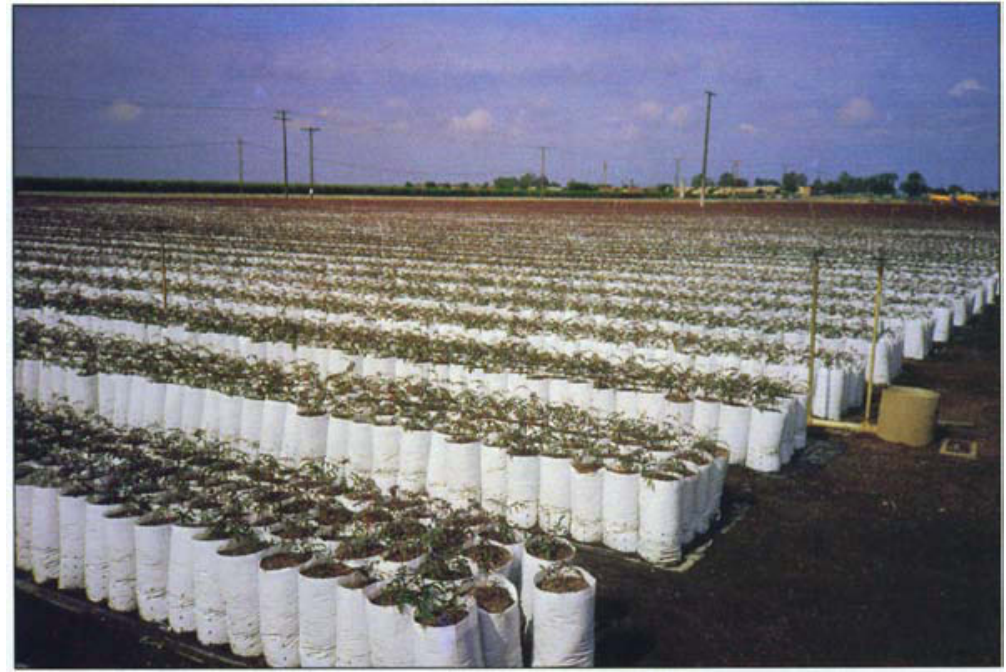

California Department of Food and Agriculture has approved a solarization technique to assure nematode-free production of container-grown nursery stock.

ance for surviving pathogen propagules deeper in the soil. However, in containerized nursery production, solarization can provide complete eradication of pests. A "double-tent" solarization technique, which functions in much the same way as the greenhouse treatment just described, was approved by the California Department of Food and Agriculture in 1999 for nematode-free production of container-, flat- and frame-grown nursery stock. Among other mandated details, the approved treatment specifies solarization of soil at a minimum of $158^{\circ} \mathrm{F}$ $\left(70^{\circ} \mathrm{C}\right)$ for at least 30 contiguous minutes (Stapleton et al. 1999).

Open field production (annual crops). Open field cultivation of row crops is the setting in which solarization was first discovered and tested. Soil to be treated should be thoroughly moistened either by preirrigation or by drip irrigation beneath the clear plastic film. Soil can be solarized in fields by either complete coverage or by covering only the planting beds. This technique works best with shallow-rooted, late-season crops in warmer locations so that the solarization can be done between crops in the summer. Complete "how-to-do-it" instructions are contained in DANR bulletin \#21377

(Elmore et al. 1997).

Open field production (permanent crops). Solarization can be modi- fied for use in managing certain weed, disease and nematode pests before or during establishment or replanting of orchard and vineyard crops, especially in warm areas such as the Central Valley. The method is most useful for managing shallowly distributed pests. It would not be expected to effectively control nematodes, fungi and other pests deep in the soil.

When using solarization in conjunction with growing plants, treatment with black, rather than clear, plastic film may be preferable. For example, early studies indicated that solarization with clear plastic film beginning shortly after planting killed almond and apricot trees due to excessive heat. However, similar treatment with black film controlled the disease Verticillium wilt without damaging the trees. Other benefits included conservation of soil moisture and reducing humidity in the crop canopy (Elmore et al. 1997). This type of solarization is mainly used on a commercial basis in the Central Valley for Prunus spp. and citrus. Industry sources estimated that at least 2,000 acres were treated in this manner in 1999 (Stapleton, unpublished data).

Although solarization can be an effective soil disinfestant, the standalone process, which largely depends on passive solar heating, has inherent limitations. Fortunately, it is compatible with other physical, chemical and biological methods of soil disinfestation to provide more efficacious and/ or predictable treatment through integration. As MB is phased out, many current users will turn to other pesticides for soil disinfestation. Combining these pesticides (perhaps at lower dosages) with solarization (perhaps for a shorter treatment period) may prove to be the most popular option for users in warm climatic areas who want to continue using chemical soil disinfestants.

\section{Biofumigation of soil}

Another useful combination is solarization with various organic amendments that have pesticidal activity when incorporated into soil. Various mechanisms of pesticidal activity have been reported for these amendments. Some may facilitate a shift in soil to a community of microflora that are antagonistic to certain soilborne pests. Others release biotoxic compounds during their degradation in soil. This latter process, especially when volatile compounds are released into the soil atmosphere by the decomposing amendments, is popularly known as "biofumigation" (Stapleton 1998).

The biofumigation phenomenon has been exemplified by studies done by various UC researchers, showing that combining solarization with residues of cabbage or other Brassica spp., as well as composted animal manures, provided improved disease management via enhanced release of biotoxic volatile compounds from the amendments in heated soil (RamirezVillapudua and Munnecke 1987; Gamliel and Stapleton 1993a, 1993b). Other studies have reported fungicidal activity of Brassica residues in coastal soils without solar heating (Subbarao et al. 1999).

\section{Nonconventional users}

Solarization is presently used on a relatively small scale in conventional California agriculture, but its use will probably increase as MB becomes unavailable. On the other hand, solarization has become a widespread practice for organic growers, home gardeners and other users who cannot or will not use chemical soil disinfestants. As an indicator of adoption, a California Certified Organic Farmers (CCOF) database shows the following historical use of solarization among its members for weed and/or disease control: in 1995, 11 growers farming 6,152 acres; in 1997, 35 growers farming 4,693 acres; and in 1998, 34 growers farming 
6,728 acres (CCOF, personal communication).

Based on the authors' field observations, most organic growers who use solarization combine it with biofumigation, primarily by adding various composts, manures, teas and other organic amendments to the soil before solarizing.

In addition to commercial applications, the widespread use of solarization in home and community gardening should be noted. Although most home gardeners do not have access to chemical soil disinfestants, solarization has become a mainstream cultural practice and contributes to improved plant health and production in this setting.

\section{MB alternatives}

It is becoming clear that few, if any, alternatives are presently available that can directly replace MB for soil fumigation under a wide variety of environmental conditions and for a broad spectrum of pests. A few soil fumigants are being used commercially in place of MB in California. When applied under optimal conditions, these materials - including 1,3-dichloropropene, chloropicrin, metam sodium and others - alone and in combination, may provide pest control efficacy similar to that of MB. However, these materials tend to provide a narrower spectrum of control than $M B$, have less predictable efficacy, and may have their own problems with environmental pollution and safety. In addition to soil fumigants, many nonfumigant chemicals (fungicides, herbicides, bactericides and nematicides) can be used for soil disinfestation, as well as an array of physical, cultural and biological methods including soil steaming (nursery production), host-plant resistance, crop rotation, antagonistic microorganisms and others. Where practical, soil solarization and biofumigation can be of benefit to users, whether or not they choose to employ soil pesticides.

\section{References}

Chen Y, Gamliel A, Stapleton JJ, Aviad T. 1991. Chemical, physical and microbial changes related to plant growth in disinfested soils. In: Katan J, DeVay JE (eds.). Soil Solarization. Boca Raton, FL: CRC Press. P 103-29.

DeVay JE, Stapleton JJ, Elmore CL (eds.). 1991. Soil Solarization. Plant Production and Protection Paper 109. Rome: FAO/ UN. $396 \mathrm{p}$.

Elmore CL, Roncaroni JA, Giraud DD. 1993. Perennial weeds respond to control by soil solarization. Cal Ag 47(1):19-22.

Elmore CL, Stapleton JJ, Bell CE, DeVay JE. 1997. Soil solarization: A nonpesticidal method for controlling diseases, nematodes and weeds. UC DANR Pub. 21377, Oakland, CA. $14 \mathrm{p}$.

Gamliel A, Stapleton JJ. 1993a. Characterization of antifungal volatile compounds evolved from solarized soil amended with cabbage residues. Phytopathology 83:899905.

Gamliel A, Stapleton JJ. 1993b. Effect of soil amendment with chicken compost or ammonium phosphate and solarization on patho- gen control, rhizosphere microorganisms and lettuce growth. Plant Disease 77:886-91.

Katan J. 1987. Soil solarization. In: Chet I (ed.). Innovative Approaches to Plant Disease Control. New York: John Wiley \& Sons. p 77-105.

Ramirez-Villapudua J, Munnecke DM. 1987. Control of cabbage yellows (Fusarium oxysporum f. sp. conglutinans) by solar heating of fields amended with dry cabbage residues. Plant Disease 71:217-21.

Stapleton JJ. 1997. Solarization: An implementable alternative for soil disinfestation. In: Biological and Cultural Control of Plant Diseases 12:1-6. St. Paul, MN: APS Press.

Stapleton JJ. 1998. Modes of action of solarization and biofumigation. In: Stapleton JJ, DeVay JE, Elmore CL (eds.). 1998. Soil Solarization and Integrated Management of Soilborne Pests. Plant Production and Protection Paper 147. Rome: FAO/UN. p 78-88.

Stapleton JJ. 2000. Soil solarization in various agricultural production systems. Crop Protection 19:837-41.

Stapleton JJ. (In press.) Soil fumigants. In: Maloy OC, Murray TD (eds.). Encyclopedia of Plant Pathology. New York: John Wiley \& Sons.

Stapleton JJ, McKenry MV, Ferguson L. 1999. Methyl bromide alternatives: CDFA approves a solarization technique to ensure against nematode pest infestation of containerized nursery stock. UC Plant Protection Quarterly 9(2):14, www.uckac.edu/ucppq.

Subbarao KV, Hubbard JC, Koike ST. 1999. Evaluation of broccoli residue incorporation into field soil for Verticillium wilt control in cauliflower. Phytopathology 88:1046-55.

[USDA] U.S. Department of Agriculture. 2000. Economic implications of the methyl bromide phaseout. Agriculture Information Bulletin \#756. 